\section{Succinilcolina: 50 Anos de Soberania}

\section{Senhor Editor,}

A succinilcolina foi introduzida na prática clínica em $1951^{1} \mathrm{e}$, a despeito de seus inúmeros para-efeitos, continua sendo empregada até os dias atuais.

A incidência de complicações graves, tais como o desencadeamento da Síndrome da Hipertermia Maligna e a hipercalemia fatal, tem levado os pesquisadores a buscar novos agentes do tipo não-despolarizante. Assim foram introduzidos no mercado o rocurônio e o rapacurônio, o primeiro um agente de duração intermediária e o segundo classificado como esteróide de curta duração.

A instalação rápida nas cordas vocais e a relativa estabilidade cardiovascular vem consagrando o rocurônio para uso em estômago cheio ${ }^{2-6}$. Primeiramente se preconizou o uso de doses de $0,6 \mathrm{mg} \cdot \mathrm{kg}^{-1}$ para intubação traqueal ${ }^{5,7,8} \mathrm{com}$ relatos de sucesso de intubação semelhantes ao obtido com a succinilcolina. Com o evoluir das observações clínicas e das pesquisas, concluiu-se que doses de $1 \mathrm{mg} \cdot \mathrm{kg}^{-1}$ ou mesmo doses superiores a $2 \mathrm{mg} \cdot \mathrm{kg}^{-1}$ devem ser empregadas quando se deseja garantia de tempo e de condições de intubação semelhantes as registradas com a succinilcolina ${ }^{3,9-15}$. No entanto, a despeito de se obter excelentes condições de intubação traqueal, essas altas doses de rocurônio implicam em uma duração de ação expressivamente maior, limitando o uso da técnica em procedimentos curtos ${ }^{14}$. Outro ponto de merece ser considerado é a indicação do rocurônio a pacientes com sinais clínicos ou história de possibilidade de intubação traqueal difícil. Nesses casos é preferível a opção por outras técnicas que assegurem as vias aéreas permeáveis, pois a duração prolongada impõe riscos ao paciente ${ }^{4}$.

A presença de reações anafiláticas, que pareciam ser mais freqüentes com o uso da succinilcolina, está merecendo atenção de especialistas no assunto (H 63, Laxenaire Besfast). Nos últimos 2 anos, na França, o maior número de reações alérgicas tem sido observado com o rocurônio, ultrapassando o número de casos com a succinilcolina, atracúrio, mivacúrio e com o vecurônio ${ }^{16}$.

O rapacurônio, um bloqueador neuromuscular adespolarizante que não chegou a ser lançado no Brasil, apresenta um início de ação muito rápido, e doses de $1,5 \mathrm{mg} \cdot \mathrm{kg}^{-1}$ propiciam excelentes ou boas condições de intubação traqueal ${ }^{17,18}$, com uma duração de ação considerada curta ${ }^{18}$. No entanto, após alguns meses de uso clínico, já se observou a alta incidência de complicações graves, como o broncoespasmo de origem não totalmente esclarecida ${ }^{19-21}$. Outro ponto que suscitou cautela é o seu mecanismo de ação, identificado como uma "redistribuição". Drogas que dependem de redistribuição para seu término de efeito estão sujeitas a serem convertidas em fármacos de duração prolongada, na dependência da dose e de doenças associadas ${ }^{18}$. A despeito desse produto ter como grande vantagem o rápido início de ação e reversão com graus profundos de relaxamento, os efeitos cardiovasculares e a presença de metabólitos ativos em regimes de infusão contínua, igualmente limitaram o uso clínico do rapacurônio. Aparentemente todos esses fatos levaram o fabricante a suspender a comercialização do produto.

Há novas drogas em fase de pesquisa em animais, promissoras no que tange a substituição da succinilcolina e para reversão rápida do rocurônio empregado em doses altas. Trata-se do TAAC 3 e do ORG 25 969. A primeira é um derivado éster di-tropinil formada por 3 isômeros que, em animais de laboratório, mostrou um início de ação até mais breve do que o da succinilcolina e um índice de recuperação em torno de 0,84 minutos versus 2,4 minutos observados com a succinilcolina ${ }^{22,23}$. Esse novo composto apresenta efeitos cardiovasculares dose dependentes, caracterizados por resposta bifásica: hipotensão seguida de hipertensão arterial, que não necessita intervenção farmacológica ${ }^{24}$. O ORG 25969 é uma ciclodextrina, mais precisamente uma $\gamma$ ciclodextrina, composta por 8 moléculas de açúcar no seu anel principal. Mostrou, em macaco Rhesus, uma reversão imediata do bloqueio motor por mecanismo que implica em formação de complexos moleculares com os bloqueadores neuromusculares do tipo esteroidal. Esse mecanismo de ação é único entre os agentes reversores, e como tal, pode ser administrado em graus profundos de relaxamento muscular. É o verdadeiro "antagonista" dos bloqueadores neuromusculares. Dentre as vantagens do seu uso cita-se a reversão rápida, a prevenção da curarização residual com conseqüente redução nas complicações pulmonares pós-operatórias, ausência de efeitos muscarínicos ou nicotínicos secundários a administração de atropina ou neostigmina e fracos efeitos hemodinâmicos ${ }^{25-27}$. Cabem ainda os estudos em seres humanos, principalmente no que tange às interações medicamentosas ${ }^{27}$.

O emprego do rocurônio para assegurar o controle das vias aéreas implica em administração de doses altas com conhecidas repercussões clínicas, e a despeito do largo uso desse relaxante para intubação traqueal rápida, efeitos indesejáveis tem sido descritos. Com a saída do rapacurônio do mercado, e enquanto não se estabelece posição definitiva para o TAAC 3 e para o ORG 25969 , a succinilcolina permanece soberana para uso em emergências médicas.

Dra. Maria Cristina Simões de Almeida, TSA Rua Renato Barbosa, 227 - Jurerê 88053-640 Florianópolis, SC

\section{Succinylcholine: 50 Years of Sovereignty}

\section{Mr. Editor,}

Succinylcholine was introduced in clinical practice in $1951^{1}$ and is still being used in spite of its numerous side-effects.

The incidence of severe complications, such as Malignant Hyperthermia Syndrome and fatal hyperkalemia, has led investigators to look for new non-depolarizing agents, like rocuronium and rapacuronium, which are available in the market; the first is an intermediate duration agent and the second is classified as a short-duration steroid.

Short onset time for vocal cords relaxation and relative cardiovascular stability have elected rocuronium as a good choice in the presence of gastric content ${ }^{2-6}$. It was initially preconized in 0.6 mg.kg-1 doses for tracheal intubation ${ }^{5,7,8}$, with successful intubation reports similar to those obtained with succinylcholine. With the development of clinical observations and research, it was found that $1 \mathrm{mg} \cdot \mathrm{kg}^{-1}$ doses or even doses higher than $2 \mathrm{mg} \cdot \mathrm{kg}^{-1}$ may be used when the goal is to assure intubation time and conditions similar to those obtained with succinylcholine ${ }^{3,9-15}$. However, is spite of excellent tracheal intubation conditions, such high rocuronium doses imply significantly longer duration, thus counterindicating the technique for short procedure ${ }^{14}$. Moreover, rocuronium indication in patient with clinical signs or history of difficult tracheal intubation has to be carefully considered in face of the risk of a prolonged neuromuscular block in a patient who can't be intubated ${ }^{4}$. 
Anaphylactic reactions, which seemed more frequent with succinylcholine, are drawing special attention ( $\mathrm{H} 63$, Laxenaire Belfast). In the last 2 years, there has been an increasing number of rocuronium allergic reactions in France, outdoing the number of cases with succinylcholine, atracurium, mivacurium and vecuronium ${ }^{16}$.

Rapacuronium, a short acting non-depolarizing neuromuscular blocker - not never launched in Brazil - has a short onset time, with $1.5 \mathrm{mg} \cdot \mathrm{kg}^{-1}$ doses allowing or good excellent tracheal intubation conditions ${ }^{17,18}$. However, after some months of clinical use, a high incidence of severe complications has already been observed, such as bronchospasm of questionable origin ${ }^{19-21}$. Other caveat is it mechanism, defined as "redistribution". Drugs depending on redistribution for reversion of effects are subject to becoming prolonged duration drugs, depending on the dose and associated conditions ${ }^{18}$. Although the advantage of fast onset and reversion with deep relaxation degrees, cardiovascular effects and the presence of active metabolites in continuous infusion regimens have limited the clinical use of rapacuronium. It seems that all these factors have led the manufacturer to withdraw the product from the market.

There are new drugs under animal trials which are promising in replacing succinylcholine and also exhibiting faster reversion compared with high doses of rocuronium. We are talking about TAAC 3 and ORG 25 969. The first is an ether di-tropinyl-derived drug, made up of 3 isomers, which in lab animals has shown an onset time even shorter that succinylcholine, and a recovery index of 0.84 minutes as compared to 2.4 minutes observed with succinylcholine ${ }^{22,23}$. This new compound presents dose-dependent cardiovascular effects, characterized by a two-phase response: arterial hypotension followed by arterial hypertension, not requiring pharmacological intervention ${ }^{24}$.

ORG 25969 is a cyclodextrine, more precisely a $\gamma$-cyclodestrine, made up of 8 sugar molecules in its major ring. In Rhesus monkeys, it has shown an immediate motor block reversion by a mechanism implying the formation of molecular complexes with steroidal-type neuromuscular blockers. This action mechanism is unique among blocker agents and, as such, may be administered for deep muscle relaxation degrees. It is the true neuromuscular blocker "antagonist". Among its advantages, one may mention fast reversion, residual curarization prevention with a consequent decrease in postoperative pulmonary complications, absence of muscarinic or nicotinic effects secondary to the administration of atropine or neostigmine and mild hemodynamic effects ${ }^{25-27}$. Human studies are still lacking, especially regarding drug interactions ${ }^{27}$.

A rocuronium choice to assure airways control implies high dose administration, with well-known clinical consequences. In spite of the wide use of this relaxant for fast tracheal intubation, undesirable effects have been reported. With rapacuronium market withdrawal, and while a permanent position for TAAC 3 and ORG 25969 are not determined, succinylcholine remains sovereign for medical emergencies.

Maria Cristina Simões de Almeida, TSA, M.D.

Rua Renato Barbosa, 227 - Jurerê

88053-640 Florianópolis, SC

\section{REFERÊNCIAS - REFERENCES}

01. Dorkins HR - Suxamethonium-the development of a modern drug from 1906 to the present day. Med Hist, 1982;26: 145-68.

02. Vianna PTG, D'Angelo SM, Estrada LEN et al - Uso de rocurônio na seqüência de intubação rápida em paciente tetraparético e com hérnia de hiato. Rev Bras Anestesiol, 1996;46:(Supl 21): 146.
03. McCourt KC, Salmela L, Mirakhur RK et al - Comparison of rocuronium and suxamethonium for use during rapid sequence induction of anaesthesia. Anaesthesia, 1998;53: 867-871.

04. Engbaek J, Viby-Mogensen J - Can rocuronium replace succinylcholine in a rapid-sequence induction of anaesthesia? Acta Anaesthesiol Scand, 1999;43:1-3.

05. Dobson AP, McCluskey A, Meakin G et al - Effective time to satisfactory intubation conditions after administration of rocuronium in adults. Comparison of propofol and thiopentone for rapid sequence induction of anaesthesia. Anaesthesia, 1999;54: 172-176.

06. Abouleish E, Abboud T, Lechevalier T et al - Rocuronium (Org 9426) for caesarean section. Br J Anaesth, 1994;73: 336-341.

07. Cooper R, Mirakhur RK, Clarke RS et al - Comparison of intubating conditions after administration of Org 9246 (rocuronium) and suxamethonium. Br J Anaesth, 1992;69: 269-273.

08. Wierda JM, de Wit AP, Kuizenga K et al - Clinical observations on the neuromuscular blocking action of Org 9426, a new steroidal non-depolarizing agent. Br J Anaesth, 1990;64: 521-523.

09. Vianna PTG, Ganem EM, Takata I - Avaliação comparativa do tempo de latência da succinilcolina e do rocurônio. Rev Bras Anestesiol, 1996;46:147.

10. Sparr HJ, Mitterschiffthaler G - Are only large doses of rocuronium an alternative to succinylcholine for rapid-sequence induction? Anesthesiology, 1994;80:1411-1412.

11. Kirkegaard-Nielsen $H$, Caldwell JE, Berry PD et al - Rapid tracheal intubation with rocuronium: a probability approach to determining dose. Anesthesiology, 1999;91:131-136.

12. Andrews JI, Kumar N, van den Brom RH et al - A large simple randomized trial of rocuronium versus succinylcholine in rapid-sequence induction of anaesthesia along with propofol. Acta Anaesthesiol Scand, 1999;43:4-8

13. Cooper RA, Mirakhur RK, Maddineni VR - Neuromuscular effects of rocuronium bromide (Org 9426) during fentanyl and halothane anaesthesia. Anaesthesia 1993;48:103-105.

14. Heier T, Caldwell JE - Rapid tracheal intubation with large-dose rocuronium: a probability-based approach. Anesth Analg, 2000;90: 175-179.

15. Magorian T, Flannery KB, Miller RD - Comparison of rocuronium, succinylcholine, and vecuronium for rapid-sequence induction of anesthesia in adult patients. Anesthesiology, 1993;79: 913-918.

16. Laxenaire MC - Epidemiology of Anaphylaxis to Muscle Relaxants, em: $7^{\text {th }}$ International Neuromuscular Meeting, 2001; Belfast, 2001.

17. Miguel R, Witkowski T, Nagashima H et al - Evaluation of neuromuscular and cardiovascular effects of two doses of rapacuronium (ORG 9487) versus mivacurium and succinylcholine. Anesthesiology, 1999;91:1648-1654.

18. Donati F. Neuromuscular blocking drugs for the new millennium: current practice, future trends - comparative pharmacology of neuromuscular blocking drugs. Anesth Analg, 2000;90:(Suppl 5):2-6.

19. Goudsouzian NG - Rapacuronium and bronchospasm. Anesthesiology, 2001;94:727-728.

20. Naguib M - How serious is the bronchospasm induced by rapacuronium? Anesthesiology, 2001;94:924-925.

21. Meakin GH, Pronske EH, Lerman J et al - Bronchospasm after rapacuronium in infants and children. Anesthesiology, 2001;94: 926-927.

22. Van Egmond J, Booij L - New Fast Neuromuscular Blocking Agent TAAC- 3 in the Anesthetized Monkey, em: $7^{\text {th }}$ International Neuromuscular Meeting; 2001; Belfast; 2001.

23. Kenneth AMAW - Studies on a New Rapid Onset and Short-Acting Neuromuscular Blocking Agent (NMBA), TAAC-3, in Anesthetized Cats, em: $7^{\text {th }}$ International Neuromuscular Meeting; 2001; Belfast; 2001.

24. Muir A - Studies in the Search for New Short-Acting Neuromuscular Blocking Agents, em: $7^{\text {th }}$ International Neuromuscular Meeting; 2001; Belfast; 2001.

25. Hope FBA - Org 25969 Reverses Rocuronium Induced Neuromuscular Blockade in the Cat without Important Hemodynamic Effects, em: $7^{\text {th }}$ International Neuromuscular Meeting; 2001; Belfast; 2001.

26. Miller SBA - Org 25969 Causes Selective Reversal of Neuromuscular Blockade Induced by Steroidal NMB's in the Mouse Hemi-Diaphragm Preparation, em: $7^{\text {th }}$ International Neuromuscular Meeting; 2001; Belfast; 2001.

27. Mason RBA - Org 25969 Causes Selective Reversal of Neuromuscular Block Induced by Steroidal NMB's in Anaesthe- tised Guinea Pigs, em: $7^{\text {th }}$ International Neuromuscular Meeting; 2001; Belfast; 2001. 